\title{
KEBIJAKAN ZONASI DAN TATA RUANG PENATAAN DAN PEMBINAAN PASAR TRADISIONAL DAN TOKO MODERN DI KABUPATEN SUMENEP
}

\author{
Moh. Ikmal ${ }^{1)}$, Suluh Mardika Alam ${ }^{2)}$ \\ Sekolah Tinggi Keguruan dan Ilmu Pendidikan PGRI Sumenep \\ ikmal.uny@gmail.com
}

\begin{abstract}
Abstrak
Upaya manusia dalam memenuhi kebutuhan hidupnya terus berlangsung melalui berbagai cara dan bentuk. Salah satu bentuk pemenuhan kebutuhan hidup masyarakat adalah melalui berdagang. Perdagangan menjadi pintu interaksi sosial masyarakat dalam memenuhi kebutuhan hidupnya. Pasar menjadi salah satu sarana manusia untuk melakukan aktivitas transaksi jual beli barang dan jasa. Pertumbuhan pasar tidak hanya terjadi pada pasar tradisional, bahkan toko-toko modern seperti minimarket, supermarket, departemen store, hypermarket maupun grosir hampir menjamur ditanah air. Namun tingginya pertumbuhan toko modern saat ini justru menghadirkan kekhawatiran tersendiri bagi keberadaan pasar tradisional yang ada. Tahun 2010 survei yang dilakukan oleh AC Nielsen menggambarkan toko modern meningkat 31,4 persen pertahun, sedangkan pasar tradisional menurun 8,01 persen. Pasar tradisional Marengan adalah merupakan salah satu pasar tradisional di kabupaten sumenep yang tidak hanya belum memiliki fasilitas-fasilitas publik yang layak semisal lahan parkir, tempat ibadah dan kamar mandi serta toilet, namun juga keberadaannya juga terancam punah dikarenakan berdekatan dengan took modern (minimarket) yang berdiri dilokasi 200 meter dari pasar tersebut. Pertumbuhan minimarket yang berdiri dilokasi yang mendekati pasar-pasar tradisional tersebut memaksa Pemerintah Kabupaten Sumenep untuk melakukan perlindungan, pemberdayaan pasar tradisional melalui Peraturan Daerah Nomor 5 Tahun 2013 tentang perlindungan, pemberdayaan pasar tradisional.
\end{abstract}

Kata kunci: Kebijakan, Pasar tradisional, Toko modern

\begin{abstract}
Human efforts to fulfill their needs continue through various ways and forms. One form of fulfilling people's living needs is through trading. Trade is the door to community social interaction in meeting their daily needs. The market is one of the human means to carry out buying and selling transaction activities for goods and services. Market growth does not only occur in traditional markets, even modern shops such as minimarkets, supermarkets, department stores, hypermarkets and wholesalers are almost mushrooming in the land. But the high growth of modern stores today presents its own concerns for the existence of traditional markets. In 2010 a survey conducted by AC Nielsen described modern stores as increasing by 31.4 percent per year, while traditional markets declined by 8.01 percent. Marengan traditional market is one of the traditional markets in Sumenep district which not only does not have proper public facilities such as parking lots, places of worship and bathrooms and toilets, but its existence is also endangered due to the proximity of modern shops (minimarkets) stand in the location of 200 meters from the market. The growth of minimarket that was established in a location that approached traditional markets forced the Sumenep Regency Government to protect, empower traditional markets through Regional Regulation No. 5 of 2013 concerning protection, empowering traditional markets.
\end{abstract}

Keyword : Policy, Traditional Market, Modern Store 


\section{PENDAHULUAN}

Seiring dengan dukungan kebijakan Negara terhadap perluasan peningkatan sector usaha masyarakat sebagai konsekuensi tuntutan demokrasi ekonomi dalam segala bidang. Pemerintah melalui berbagai regulasi terus mendorong bahkan ikut serta mengawasi tingkat pertumbuhan pasar baik pasar tradisional maupun modern yang ada. Lahirnya UU No. 5 tahun 1999, UU No. 26 tahun 2007, Perpres RI No.112 tahun 2007, Permendagri No. 56 tahun 2014, bahkan pada tingkat lokal Kabupaten Sumenep adalah wujud nyata kepedulian pemerintah dalam pengelolaan dan pembinaan sektor industry usaha.

Namun ditengah tingginya pertumbuhan toko modern saat ini justru menghadirkan kekhawatiran tersendiri bagi keberadaan pasar tradisional yang ada. Pada tahun 2010 survei yang dilakukan oleh AC Nielsen menggambarkan toko modern meningkat 31,4 persen pertahun, sedangkan pasar tradisional menurun 8,01 persen. Data kementerian perindustrian tahun 2007 dan kementrian perdagangan tahun 2011 menyebutkan adanya jumlah penurunan pertumbuhan pasar tradisional secara drastis. Pada tahun 2007 jumlah pasar tradisional Indonesia mencapai 13.450 tapi pada tahun 2011 jumlahnya tinggal $9.950^{1}$. Di sektor makanan, pangsa pasar Supermarket meningkat dari 11 persen menjadi 40 persen. Selain mengalami pertumbuhan dari sisi jumlah dan angka penjualan, peritel modern mengalami pertumbuhan pangsa pasar yang pesat. Selain itu, Ikatan Pedagang Pasar Indonesia (IKAPPI) menyatakan, perkembangan pasar rakyat cukup memprihatinkan. Data IKAPPI mengungkapkan, pasar rakyat mengalami penurunan hingga 81 persen. Padahal, ada 50-an juta rakyat bergantung dari pasar tradisional ${ }^{2}$. Kondisi pertumbuhan diatas memberikan penegasan sekaligus keprihatinan bahwa disamping keberadaan toko modern memang membawa

\footnotetext{
${ }^{1}$ Nusantaranews.co, 28 september 2017"stop kooptasi warung rakyat melalui dominasi distribusi ritel modern" diakses di http://nusantaranews.co/stop-kooptasi-warung-rakyat-melaluidominasi-distribusi-ritel-modern/

2 Bisnis. "Perkembangan Pasar di Indonesia" dikutip dari http://www.bisnis.com <diunduh tanggal 12 September 2015>
}

pertumbuhan yang pesat bagi perekonomian Negara namun disisi lain keberadaannya dapat mengancam keberdaan pasar tradisional yang ada. Oleh karena itu penting untuk memperhatikan persoalan zonasi maupun pada aspek lainnya guna menjamin iklim persaingan usaha yang sehat antar pelaku usaha (pasar tradisional dan toko modern) yang ada. Pemerintah pusat maupun daerah melalui peraturan perundang-undangan telah mengatur perihal penataan ruang, pendirian usaha (tradisional dan modern), larangan praktek monopoli serta pedoman pembinaan pasar tradisional, pusat perbelanjaan dan toko modern.

Tingginya pertumbuhan toko modern barangkali seiring dengan tingginya minat dan persepsi masyarakat yang menilai toko modern lebih memberikan nuansa yang nyaman, bersih dan memadai. Kondisi ini justru sangat berbeda dengan pengelolaan pasar tradisional yang masih jauh dari standard-standar kelayakan, kenyamanan dan kebersihan serta masih belum tersedianya fasilitas-fasilitas umum yang layak bagi pengunjung. Kementerian Perdagangan menilai bahwa pengelolaan pasar tradisional masih bermasalah sehingga memberikan persepsi negatif kepada masyarakat. Persoalan utama adalah pengelolaan yang bermasalah sehingga pasar tradisional tidak berjalan optimal. Fenomena semacam ini hampir terjadi diberbagai daerah di kawasan Sumenep tak terkecuali Kecamatan Kalianget.

Pasar tradisional Marengan merupakan salah satu pasar tradisional yang terletak di Kecamatan Kalianget yang masih belum memiliki fasilitas-fasilitas publik yang layak semisal lahan parkir, tempat ibadah dan kamar mandi serta toilet. Padahal ketersedian fasilitas-fasilitas ini menjadi kewajiban pengelola pasar sebagaimana diatur dalam beberapa kebijakan pemerintah seperti Peraturan Daerah No. 05 Tahun 2013 maupun Peraturan Presiden No. 112 Tahun 2007 bahwa baik pasar tradisional maupun toko modern harus menyediakan areal pakir yang 
cukup dan saranan umum lainnya3. Sementara disisi lain, kehadiran pedagang kaki lima (PKL) disisi luar bangunan pasar merupakan salah satu masalah yang dihadapi pasar tradisional. Keberadaan PKL semakin menambah kesan kumuh dan semrawut yang biasanya mewarnai pasar tradisional dan mengancam keberadaan pedagang yang menyewa kios dipasar tradisional. Menjamurnya PKL di sekitar pasar tradisional berkaitan erat dengan masalah pengelolaan pasar. Oleh karena itu, upaya mengatasi dampak kehadiran PKL di pasar tradisional tidak dapat dilepaskan dari pengelolaan pasar yang baik. Para PKL yang menggelar dagangan di depan pasar sampai bahu jalan seringkali menimbulkan kemacetan lalu lintas dan turut menimbulkan ketidaknyamanan berbelanja di pasar tradisional.

Ditengah meningkatnya ekspektasi masyarakat terhadap keberadaan pasar tradisional yang nyaman dan bersih, justru keberadaan pasar tradisional telah mulai kehilangan eksistensinya dan ada pula yang gulung tikar hal ini disamping disebabkan karena kurang tanggapnya pemerintah terhadap keberadaan pasar tradisional dari praktek usaha yang tidak sehat akibat praktek monopoli. Banyak pasar tradisional yang kurang dan ada pula yang tidak sama sekali diurus atau ditanggapi oleh pemerintah. Selain itu mulai banyaknya pertumbuhan minimarket yang berdiri dilokasi yang mendekati pasar-pasar tradisional. Ditengah kondisi pasar tradisional yang sangat memprihatinkan seperti becek, bau, banyak sampah yang dibuang sembarangan juga menjadi kelemahan bagi pasar tradisional, sehingga sebagian masyarakat kita memilih untuk berbelanja di toko-toko modern yang cenderung lebih baik dari segi pelayanan dan fasilitas.

Kompleksitas persoalan yang dihadapi baik oleh keberadaan pasar tradisional maupun toko modern baik pada persoalan ketersediaan fasilitas-fasilitas public yang nyaman dan bersih hingga pada persoalan zonasi pendirian toko modern tersebut telah memaksa Pemerintah Kabupaten Sumenep

\footnotetext{
${ }^{3}$ Lihat pasal 6 ayat 2 Peraturan Daerah Kabupaten Sumenep No.5 Tahun 2013 dan Pasal 2 Ayat 2 Perpres No. 112 Tahun 2007
}

untuk melakukan perlindungan, pemberdayaan pasar tradisional melalui perda diatas. Tentunya kehadiran Perda tersebut sebagai respon terhadap kondisi pasar yang ada. Kondisi infrastruktur pasar sejauh ini masih belum bisa membuat nyaman pedagang dan pengunjung pasar karena memang jauh dari memadai. Kondisi yang demikian justru akan berpengaruh terhadap sumbangsih pasar kepada pemasukan. Dinas Pendapatan Pengelola Keuangan dan Aset (DPPKA) Sumenep, pada perubahan APBD tahun 2015 lalu misalnya menganggarkan pembenahan atau perbaikan pasar di sejumlah kecamatan, yaitu di tiga lokasi dengan besaran $\mathrm{Rp} 1,7$ miliar. Dengan anggaran tersebut dan setelah pasar dibenahi, diyakini akan diikuti oleh PAD yang memadai terhadap daerah. Berdasarkan kerangka permasalahan diatas maka tujuan penelitian ini dilakukan dalam rangka menggali bagaimana kebijakan Pemerintah Kabupaten Sumenep dalam menangani permasalahan penataan Pasar Tradisional Marengan baik aspek zonasi dan tata ruangnya.

\section{METODE}

Penelitian ini merupakan penelitian kualitatif-deskriptif. Penelitian kualitatif yang dimaksud adalah penelitian yang dilakukan secara intensif dan terperinci terhadap suatu organisme, lembaga, atau gejala tertentu melalui suatu pengamatan atau analisis untuk menghasilkan data deskriptif, yaitu data yang berupa kata-kata tertulis atau lisan dari orang, gejala atau perilaku yang diamati. Sementara pendekatan yang digunakan dalam penelitian ini adalah pendekatan induktif. Pendekatan induktif merupakan pendekatan yang bekerja mulai dari yang khusus ditarik menjadi kesimpulan umum atau dimulai dari kasus khusus untuk dianalisis dengan aturan-aturan hukum yang ada.

Teknik pengumpulan data pada penelitian ini adalah berupa kata-kata dan tindakan yang diperoleh secara langsung (data primer) berupa studi dokumen, wawancara dan observasi. Studi dokumen berupa perundangan-undangan yang memiliki relevansi dengan penelitian ini maupun dokumen dalam bentuk foto. Wawancara merupakan bentuk percakapan langsung dan tatap muka baik dengan para 
pelaku usaha pasar tradisional sebanyak lima orang maupun dengan pihak pemerintah.

Sementara guna memperoleh tingkat akurasi data lebih objektif, data yang diperoleh dibutuhkan proses analisa data. Analisis data menurut Patton adalah proses mengatur urutan data, mengorganisir data ke dalam suatu pola, kategori, dan satuan uraian data. Adapun teknik analisis data dalam penelitian ini menggunakan analisis data induktif dan evaluatif. Analisis induktif merupakan analisis data yang terlebih dahulu dimulai dari fakta-fakta hukum lalu kemudian menuju aturan-aturan hukum yang ada, sementara analisis evaluatif adalah analisis hasil data sebagai hasil proses evaluasi fakta-fakta berdasarkan peraturan-peraturan yang ada.

\section{HASIL DAN PEMBAHASAN \\ Rencana Tata Ruang Wilayah Sebagai Dasar Pengaturan Zonasi Pendirian Pasar Tradisional dan Toko Modern}

Pendirian sebuah pasar baik pasar tradisional maupun toko modern harus memperhatikan rencana tata ruang wilayah yang ada. Penataan ruang adalah suatu system proses perencanaan tata ruang, pemanfaatan ruang dan pengendalian pemanfaatan ruang. Guna mewujudkan kualitas ruang berkelanjutan yang sesuai dengan rencana tata ruang, maka diperlukan instrument pengendalian yang mencakup seluruh aspek penataan ruang. Dalam hal ini, instrumen tersebut dapat digunakan sebagai pengendalian pemanfaatan ruang wilayah/daerah untuk mengarahkan pemanfaatan zona, terutama terkait erat dengan aktivitas kota yang berkembang yang seringkali memberikan dampak buruk bagi kepentingan umum. Pasca diterbitkannya Undang-undang Nomor 05 Tahun 2015 tentang Pemerintahan Daerah dan Undang-undang Nomor 26 Tahun 2007 tentang Penataan Ruang menyebabkan terjadinya perubahan dalam hal penataan ruang, dimana daerah mempunyai hak penuh untuk melaksanakan penataan ruang di daerahnya.

Pergantian sistem pemerintahan tersebut berdampak positif terhadap penataan ruang diantaranya adalah Pemerintah Daerah dapat mengawasi pembangunan di daerahnya secara bertanggungjawab penuh sehingga pembangunan sesuai dengan aspirasi masyarakatnya. Oleh karena itu dalam upaya pengendalian pemanfaatan ruang perlu ditindaklanjuti melalui pengaturan zona (zone regulation). Peraturan Zonasi tersebut adalah ketentuan yang mengatur tentang klasifikasi zona, pengaturan lebih lanjut mengenai pemanfaatan lahan, dan prosedur pelaksanaan pembangunan. Suatu zona mempunyai aturan yang seragam (guna lahan, intensitas, massa bangunan), namun satu zona dengan zona lainnya bisa berbeda ukuran dan aturan. Pengendalian pemanfaatan ruang berdasarkan UU Nomor 26 tahun 2007 antara lain dilaksanakan melalui penerapan peraturan zonasi. Peraturan zonasi disusun sebagai pedoman pengendalian pemanfaatan ruang. Peraturan zonasi ditetapkan berdasarkan :

1. Peraturan Pemerintah untuk arahan peraturan zonasi sistem nasional;

2. Peraturan Daerah Provinsi untuk arahan peraturan zonasi sistem provinsi; dan

3. Peraturan Daerah Kabupaten/Kota untuk peraturan zonasi sistem kabupaten/ kota.

Penyusunan peraturan zonasi didasarkan pada rencana rinci tata ruang. Dalam UU Nomor 26 tahun 2007 tentang Penataan Ruang, rencana rinci tata ruang disusun sebagai perangkat operasional rencana umum tata ruang dan terbagi atas :

1. Rencana tata ruang pulau/kepulauan dan rencana tata ruang kawasan strategis nasional;

2. Rencana tata ruang kawasan strategis provinsi; dan

3. Rencana Detail Tata Ruang Kabupaten/Kota (RDTRK) dan rencana tata ruang kawasan strategis Kabupaten / Kota

Oleh karena itu guna mewujudkan system tata ruang yang terkendali pemanfaatan dan penggunaanya, Pemerintah Kabupaten Sumenep mengeluarkan Peraturan Daerah Kabupaten Sumenep Nomor 12 Tahun 2013 Tentang Rencana Tata Ruang Wilayah Kabupaten Sumenep dimana 
dalam Pasal 6 merinci bahwa kebijakan penataan ruang wilayah kabupaten meliputi :

1. Pengembangan kawasan minapolitan;

2. Pengembangan kawasan agropolitan;

3. Pengembangan dan peningkatan kawasan pariwisata;

4. Pengembangan kegiatan industri;

5. Peningkatan kualitas dan jangkauan prasarana dan sarana wilayah;

6. Pengendalian dan pengelolaan fungsi kawasan lindung;

7. Peningkatan kualitas lingkungan hidup dan pengurangan resiko bencana melalui pengelolaan fungsi kawasan lindung;

8. Pengembangan kawasan budidaya sesuai daya dukung lingkungan;

9. Pengembangan potensi pertambangan mineral dan non mineral;

10. Pengembangan kawasan pesisir dan pulau-pulau kecil

Disamping mengatur tentang kebijakan penataan ruang, dalam perda tersebut juga mengatur mengenai ketentuan umum peraturan zonasi sebagaimana tercantum dalam bagian kedua dari perda tersebut. Ketentuan zonasi adalah adalah merupakan ketentuan yang mengatur tentang persyaratan pemanfaatan ruang dan ketentuan pengendaliannya dan disusun untuk setiap blok atau zona peruntukan yang pembagian zonanya ditetapkan dalam rencana rinci tata ruang. Peraturan Zonasi Provinsi merupakan penjabaran detail dari indikasi arahan peraturan zonasi sistem provinsi dalam Rencana Tata Ruang Wilayah Provinsi. Sedangkan Peraturan Zonasi Kabupaten/Kota merupakan penjabaran detail dari ketentuan umum peraturan zonasi kabupaten/kota dalam Rencana Tata Ruang Wilayah Kabupaten/Kota.

Dalam penyusunan peraturan zonasi, definisi dan klasifikasi penggunaan lahan

\footnotetext{
${ }^{4}$ Lihat Pasal 6 Peraturan Daerah Kabupaten Sumenep Nomor 12 Tahun 2013 Tentang Rencana Tata Ruang Wilayah Kabupaten Sumenep Tahun 2013 - 2033
}

yang jelas secara hukum sangat diperlukan untuk menjadi landasan utama dan sebagai acuan untuk menentukan apakah suatu permohonan pemanfaatan akan sesuai dengan rencana atau tidak. Klasifikasi penggunaan lahan yang jelas menentukan ijin dapat diberikan atau ditolak. Selain menentukan klasifikasi pemanfaatan ruang, harus pula ditentukan klasifikasi perubahan pemanfaatan ruang, baik yang diizinkan maupun yang tidak diizinkan. Pengklasifikasian pemanfaatan ruang harus jelas, seragam, dan sederhana (tetapi tidak terlalu sederhana) dan harus berlaku umum di seluruh Indonesia sehingga rencanarencana pemanfaatan ruang dapat ditetapkan secara seragam untuk memudahkan proses pengendalian pemanfaatan

Izin pemanfaatan ruang yang dikeluarkan dan/atau diperoleh dengan tidak melalui prosedur yang benar, batal demi hukum. Izin pemanfaatan ruang yang diperoleh melalui prosedur yang benar tetapi kemudian terbukti tidak sesuai dengan rencana tata ruang wilayah, dibatalkan oleh Pemerintah dan Pemerintah Daerah sesuai dengan kewenangannya. Setiap pejabat pemerintah yang berwenang menerbitkan izin pemanfaatan ruang dilarang menerbitkan izin yang tidak sesuai dengan rencana tata ruang.

\section{Kebijakan Zonasi Pendirian Pasar Tradisional Dan Toko Modern Di Sumenep}

Hadirnya Undang-Undang Nomor 09 Tahun 2015 tentang pemerintahan daerah memberikan hak otonomi bagi masingmasing daerah untuk melaksakan pembangunan di masing-masing daerahnya. Pergantian sistem pemerintahan tersebut berdampak positif khususnya terhadap Pemerintah Daerah, dimana Pemerintah Daerah melalui Otonomi Daerahnya (menurut asas otonomi) berwenang untuk mengatur dan 
mengurus sendiri urusan pemerintahan dan kepentingan masyarakat setempat seluasluasnya (kecuali urusan pemerintahan yang menjadi urusan pemerintah pusat, seperti: politik luar negeri, pertahanan, keamanan, yustisi, moneter dan fiskal serta agama) sesuai dengan peraturan perundang undangan yang berlaku. Pergantian sistem pemerintahan tersebut berdampak positif terhadap penataan ruang, diantaranya adalah Pemerintahan Daerah dapat mengawasi pembangunan di daerahnya secara bertanggungjawab penuh sehingga pembangunan sesuai dengan aspirasi masyarakatnya. Regulasi ini diharapkan mampu mengendalikan pemanfaatan ruang sekaligus melakukan pengawasan terhadap pemanfaatan ruang yang ada. Guna kepentingan tersebut pemerintah mengaturnya dalam Undang Undang Nomor 26 Tahun 2007 tentang Penataan Ruang (Lembaran Negara Republik Indonesia Tahun 2007 Nomor 68, Tambahan Lembaran Negara Republik Indonesia Nomor 4725) dimana dalam UU penataan ruang tersebut memiliki 3 (tiga) unsur yang saling terintegrasi, yaitu:

1. Perencanaan Tata Ruang

2. Pemanfaatan Ruang

3. Pengendalian Pemanfaatan Ruang

Keberadaan kegiatan perdagangan skala besar seperti pasar modern sudah menjadi bagian yang tidak terpisahkan dari kehidupan masyaarakat perkotaan. Hal inilah yang mendorong tingginya investor untuk masuk dalam jalur perdagangan di Indonesia sehingga banyak bermunculan toko modern berupa minimarket, supermarket departemen store dan lain sebagainya. Perkembangan pasar modern yang semakin menyebar luas di Indonesia mendorong pemerintah untuk melakukan intervensi ekonomi terhadap pelaku usaha. Pendirian pasar tradisional, pusat perbelanjaan dan pasar modern telah diatur dalam perpres No. 112 tahun 2007 dimana pendiriannya mengacu kepada rencana tata ruang wilayah kabupaten/kota termasuk peraturan zonasinya. Penentuan tata ruang wilayah juga harus memperhatikan pula kondisi ekonomi, budaya maupun sosial masyarakat setempat agar invetasi tidak hanya memberikan keuntungan semata bagi pemerintah daerah setempat akan tetapi juga masyarakat setempat.

Terkait dengan unsur pengendalian pemanfaatan ruang sebagaimana disebutkan dalam Pasal 1 angka 15 Undang Undang Nomor 26 Tahun 2007 bahwa "Pengendalian Pemanfaatan Ruang adalah upaya untuk mewujudkan tetib tata ruang". Dalam upaya pengendalian pemanfaatan ruang perlu ditindaklanjuti melalui pengaturan zona (zoning regulation). Ketentuan zonasi sebagai bagian upaya pemerintah kabupaten sumenep dalam pengendalian pemanfaatan ruang terutama menyangkut ketentuan zonasi diatur dalam bab VII. Pasal 62 misalnya dijelaskan bahwa ketentuan zonasi terdiri atas zonasi struktur ruang, zonasi pola ruang dan zonasi kawasan strategis ${ }^{5}$.

Berdasarkan penjelasan tersebut maka dapat diinterpretasikan bahwa zonasi pasar tradisional dan toko modern menjadi kewenangan pemerintah daerah dengan memperhatikan kondisi sosial ekonomi masyarakat, keberadaan pasar tradisional, usaha kecil dan usaha menengah yang ada diwilayah yang bersangkutan dan memperhatikan jarak antara hypermarket dengan pasar tradisional yang telah ada sebelumnya. Berkaitan dengan perizinan pendirian tempat usaha di kabupaten Sumenep terdapat beberapa peraturan perundang-undangan yang dapat dijadikan sebagai pedoman yaitu Peraturan Daerah Nomor 5 tahun 2013 dan Peraturan Bupati Kabupaten Sumenep Nomor 14 tahun 2011 5 Peraturan Daerah Kabupaten Sumenep Nomor 12 Tahun 2013
tentang RT RW Kabupaten Sumenep Tahun 2013-2033. 
tentang Organisasi Dan Tata Kerja Pelayanan Perizinan Terpadu.

Pemerintah Kabupaten Sumenep adalah salah satu kabupaten kawasan gerbang timur pulau Madura yang dalam konteks kebijakan penataan ruang wilayahnya memiliki misi memajukan ekonomi masyarakat melalui pembangunan minapolitan, agropolitan, pariwisata dan industri. Potensi sumber daya yang dimiliki kabupaten ini membuka ruang bagi para investor guna menanamkan invetasi usaha dikabupaten sumenep, namun meski demikian berdasarkan peraturan perundang-undangan tersebut diatas para investor harus tetap memenuhi persyaratan dalam perizinan. Pemberian izin dan pencabutan izin bukanlah tugas yang sederhana bagi pemerintah karena penerbitan izin harus melalui proses kajian yang mendalam. Pengajuan perizinan di kabupaten sumenep harus memenuhi persyaratan administrasi seperti IMB, izin lokasi dan izin $\mathrm{HO}$ dengan kordinasi kasi badan pembangunan daerah kemudian baru pengurusan SIUP.

Tahun 2013 Pemerintah Kabupaten Sumenep menerbitkan Peraturan Daerah Nomor 5 Tahun 2013 tentang Perlindungan, Pemberdayaan Pasar Tradisional dan Penataan Pasar Modern. Pada tahun yang sama pula Pemerintah Kabupaten Sumenep juga mengeluarkan peraturan daerah nomor 12 tahun 2013 tentang RT RW kabupaten sumenep tahun 2013-2033. Dua regulasi diatas adalah merupakan pijakan penting bagi penataan tata ruang sekaligus pemanfaatnya yang sengaja tujuannya berfungsi sebagai strategi pengendalian dan pengawasan tata ruang wilayah.

Perkembangan toko modern yang semakin tumbuh pesat mendorong pemerintah untuk melakukan kebijakan pengawasan secara ketat terhadap prosedur pendirian usaha dimana pendirian pasar tradisional maupun toko modern wajib mengacu pada RT RW dan peraturan zonasinya. Namun ketidakjelasan pemerintah mengatur ketentuan zonasi telah mendorong tumbunya toko modern berbentuk minimarket makin tumbuh subur dan bahkan hampir berdekatan dengan pasar tradisional. Pasal 7 ayat 1 perda nomor 5 tahun 2013 menyebutkan bahwa Pendirian Pasar Tradisional atau Pusat Perbelanjaan atau Toko Modern selain Minimarket harus memenuhi persyaratan ketentuan peraturan perundang-undangan dan harus melakukan analisa kondisi sosial ekonomi masyarakat, keberadaan Pasar Tradisional dan UMKM yang berada di wilayah bersangkutan.

Oleh karena itu pertumbuhan minirmarket yang semakin tidak terkendali ini hampir meresahkan pelaku usaha pasar tradisional. Mengatasi masalah toko modern yang semakin marak perkembangannya pemerintah kabupaten Sumenep memperketat Surat Izin Usaha Perdagangan (SIUP) yang selama ini dimiliki oleh toko modern dengan ketentuan baru harus memiliki Izin Usaha Toko Modern (IUTM) sebagai pengganti SIUP. Apabila masa berlaku SIUP berakhir, pemilik SIUP harus segera menggantinya dengan IUTM. Kepala Dinas Perindustrian dan Perdagangan Kabupaten Sumenep, $\mathrm{H}$. Syaiful Bahri, M.Si menjelaskan bahwa untuk mendapatkan IUTM, tidak gampang, pengusaha harus melengkapi syarat-syarat antara lain ${ }^{6}$ :

a. copy surat izin prinsip dari Bupati;

b. hasil analisa kondisi sosial ekonomi masyarakat; serta rekomendasi dari instansi yang berwenang;

c. persetujuan pemanfaatan ruang;

d. copy surat Izin Lokasi dari Badan Pertanahan Nasional (BPN);

e. copy surat Izin Gangguan ( $\mathrm{HO})$;

f. copy surat Izin Mendirikan Bangunan (IMB);

\footnotetext{
${ }^{6}$ Hasil wawancara, 26 November 2018
} 
g. copy Akte Pendirian Perusahaan dan pengesahannya;

h. rencana kemitraan dengan Usaha Mikro dan Usaha Kecil;

i. surat pernyataan kesanggupan melaksanakan dan mematuhi ketentuan yang berlaku.

Namun sangat disayangkan bahwa dalam Peraturan Daerah Kabupaten Sumenep Nomor 5 Tahun 2013 ini belum memberikan keterangan yang spesifik mengenai berapa jarak minimal pendirian sebuah toko modern dengan toko modern lain maupun jarak antara toko modern dengan pasar serta ritel tradisional. Dalam Pasal 7 Peraturan Daerah Kabupaten Sumenep Nomor 5 Tahun 2013 ini hanya menyebutkan lokasi untuk pendirian Toko Modern selain minimarket wajib memperhatikan:

a. Rencana Tata Ruang Wilayah kabupaten dan rencana detail tata ruang kota termasuk zonasinya;

b. Kondisi sosial ekonomi masyarakat dan keberadan Pasar Tradisional, Usaha Mikro, Kecil dan Menengah yang ada di wilayah yang bersangkutan;

c. Jarak antara Toko Modern yang akan didirikan dengan Pasar Tradisional yang telah ada sebelumnya

Ketidakjelasan ketentuan Pasal 7

Peraturan Daerah Kabupaten Sumenep Nomor 5 Tahun 2013 ini yang menyebabkan banyak toko modern mengalami pelanggaran, sehingga banyak ditemukan hampir disetiap sudut kabupaten sumenep toko modern yang pola penyebarannya tidak merata dan bahkan antara toko modern satu dengan toko modern lain saling berhadap-hadapan dan yang lebih parah lagi, toko modern tersebut berjarak sangat berdekatan dengan pasar tradisional serta ritel tradisional, yang berakibat melemahnya perekonomian para pedagang di pasar dan ritel tradisional

\section{UCAPAN TERIMAKASIH}

Hasil penelitian ini tentu tidak akan dapat terlaksana dengan baik tanpa dukungan dari beberapa pihak baik lingkungan STKIP PGRI Sumenep sendiri maupun dari pihak Pemerintah Kabupaten Sumenep serta rekan-rekan mahasiswa yang juga terlibat langsung dalam proses penelitian ini. Oleh karena itu segala kebaikan penulis haturkan kepada mereka telah memberikan tenaga dan waktu demi terlaksananya penelitian dengan baik dengan harapan semoga hasil penelitian ini dapat memberikan manfaat bagi kalangan masyarakat luas, akademisi, mahasiswa maupun pemangku kebijakan di kabupaten Sumenep demi terwujudnya distribusi pembangunan yang berkeadilan.

\section{KESIMPULAN}

Kelemahan fundamental pengaturan mengenai zonasi dalam Peraturan Presiden Nomor 112 Tahun 2007 dan Peraturan Menteri Perdagangan Nomor No. 56 tahun 2014 menimbulkan suatu perbedaan interprestasi bagi setiap pemerintah daerah, meski dalam konteks penyelenggaraan pemerintahan daerah, masing-masing pemerintah daerah memiliki hak otonom untuk mengatur daerahnya sendiri namun produk hukum yang dihasilkan pemerintah daerah salah satunya pemerintah Kabupaten Sumenep yang menerbitkan Peraturan Daerah Kabupaten Sumenep Nomor 5 Tahun 2013 masih belum mampu mennghadirkan kebijakan yang lebih berpihak kepada pelaku usaha pasar tradisional. Persaingan yang semakin tidak sehat akibat pertumbuhan toko modern yang semakin tidak terkendali justru akan mengancam eksistensi pasar tradisional itu sendiri. Hadirnya perda diatas hanya memihak kepada peritel modern yang seharusnya peraturan yang diterbitkan oleh pemerintah harus memihak kepada rakyat khususnya pelaku usaha dalam pasar tradisional yang mayoritas menjalankan usahanya dengan modal kecil dibandingkan dengan pasar modern yang disokong oleh pengusaha dengan modal kuat. Aturan hukum yang diatur di Peraturan Daerah Kabupaten SumenepNomor 5 Tahun 2013 
belum mampu meng-cover kepentingan pelaku usaha khususnya pelaku usaha dalam pasar tradisional, karena norma di dalam Peraturan Daerah Kabupaten SumenepNomor 1 Tahun 2010 kurang mengikat bagi pelaku usaha pasar modern, dimana hanya mengatur mengenai ketentuan untuk memperhatikan keberadaan pasar tradisional, tanpa diatur mengenai berapa jarak minimal yang harus dipatuhi oleh calon pelaku usaha pasar modern untuk mendirikan bangunan pasar modern. Akibat dari tidak adanya aturan yang lebih konkrit lagi mengenai zonasi pasar tradisional dengan pasar modern, menyebabkan posisi pasar

\section{DAFTAR PUSTAKA}

Buku :

Arikunto, S. 1998. Prosedur Penelitian. Jakarta: Rinneka Cipta

Lexy J. Moleong, 2010, Metodologi Penelitian Kualitatif, Bandung: PT. Rosdakarya

Moleong, Lexy J. 2002. Metodologi Penelitian Kualitatif. Bandung: PT Remaja Rosda Karya

Patton, MQ, 1990. Qualitative Evaluation Methods. Beverly Hills : SAGE.

Peraturan Perundang-Undangan:

Undang-Undang Nomor 09 Tahun 2015 tentang pemerintahan daerah

Undang Undang Nomor. 5 tahun 1999 tentang larangan praktek monopoli dan persaingan

Undang Undang Nomor. 26 tahun 2007 tentang penataan ruang

Perpres RI No.112 tahun 2007 tentang penataan pasar tradisional dan toko modern
Permendagri No. 56 tahun 2014 tentang pedoman pembinaan pasar tradisional, pusat perbelanjaan dan toko modern.

Peraturan Daerah Kabupaten Sumenep No. 05 Tahun 2013 tentang perlindungan, pemberdayaan pasar tradisional dan penataan pasar pasar modern

Peraturan Daerah Kabupaten Sumenep Nomor 12 Tahun 2013 tentang RT RW Kabupaten Sumenep Tahun 2013-2033

Jurnal:

Zulfadli Barus, "Analisis Filosofis Tentang Peta Konseptual Penelitian Hukum Normative Dan Penelitian Hukum Sosiologis" Jurnal Dinamika Hukum, Vol. 13 No. 2 Mei 2013

Online :

Bisnis. "Perkembangan Pasar di Indonesia" dikutip dari http://www.bisnis.com $<$ diunduh tanggal 12 September 2015>

Koran kabar, "kondisi pasar di Pamekasan memperihatinkan", dikutip dari http://www.korankabar.com, <diunduh tanggal 23 oktober 2015>

Nusantaranews.co, 28 september 2017"stop kooptasi warung rakyat melalui dominasi distribusi ritel modern" diakses di http://nusantaranews.co/stopkooptasi-warung-rakyat-melaluidominasi-distribusi-ritel-modern/

Tempo, "potret pasar di indonesia", dikutip dari http://www.tempointeraktif.com, <diunduh tanggal 3 september 2015> 